\title{
Escapement of Broodstock Chinook Salmon From Whitlock Bay Spawning Station, Lake Oahe, South Dakota
}

\author{
Dylan A. Gravenhof \\ South Dakota Department of Game, Fish and Parks, Missouri River Fisheries Center \\ 20641 SD Highway 1806, Fort Pierre, South Dakota, 57532, United States \\ Tel: 1-605-223-7720 \\ E-mail: dylan.gravenhof@state.sd.us
}

Robert P. Hanten

South Dakota Department of Game, Fish and Parks, Missouri River Fisheries Center 20641 SD Highway 1806, Fort Pierre, South Dakota, 57532, United States

Tel: 1-605-223-7702

E-mail: robert.hanten@state.sd.us

Michael E. Barnes

South Dakota Department of Game, Fish and Parks, McNenny State Fish Hatchery 19605 Trout Loop, Spearfish, South Dakota, 57783, United States

Tel: 1-605-642-6920

E-mail: mike.barnes@state.sd.us

Received: July 8, 2020 Accepted: October 13, 2020 Published: October 21, 2020 doi:10.5296/ast.v9i1.17330 URL: https://doi.org/10.5296/ast.v9i1.17330 


\section{Abstract}

Feral spawning fall Chinook salmon (Oncorhynchus tshawytscha) in Lake Oahe, South Dakota, are captured using a fish ladder and catch raceway at Whitlock Bay Spawning Station. The number of salmon that escaped the catch raceway and descended the fish ladder prior to spawning was unknown. During October 2017, all salmon that ascended the fish ladder at the spawning station were tagged. Tagged males remained in the catch raceway. Tagged females were moved to other secure raceways and used to estimate tag retention. Of the 383 tagged males, $159(41.5 \%)$ were initially designated as escaped from the catch raceway. Tag loss in the females was 3.9\%. Thus, the estimated male salmon escapement rate from the catch raceway was 37.6\%. Male salmon remained in the catch raceway for one-to-three days before escaping. The escapement rate decreased over the month-long spawn, with nearly $60 \%$ of the males going back down the fish ladder in the first week of October, compared to less than $20 \%$ escapement by the final week. Such high rates of escapement from the spawning station may be negatively impacting the spawning efficiencies. Possible solutions include re-engineering of the fish ladder or daily removal of the salmon in the catch raceway to other more secure locations at the spawning station.

Keywords: Chinook salmon, Oncorhynchus tshawytscha, escapement, broodstock, spawning

\section{Introduction}

Wild salmon are frequently spawned to provide eggs for hatchery production (McIntyre 1991). Feral adults are typically captured by using weirs, traps, or fish ladders as they return to their natal streams to spawn (Piper et al. 1982; Brannon 1991; Schroeder 1996). Depending on the design, fish may be allowed to migrate into and out of the structure, but more frequently barriers are used to retain as many potential broodfish as possible (Leitritz and Lewis 1976; FRED 1983; Schroeder 1996).

Lake Oahe, a 150,000 ha mainstem Missouri River reservoir in North Dakota and South Dakota, USA, contains a relatively unique population of fall Chinook salmon (Oncorhynchus tshawytscha). This population is maintained entirely by hatchery stocking (Lott et al. 1997). Reproductive success during artificial propagation is typically poor, but also highly variable (Barnes et al. 2000; Young et al. 2016). Natural reproduction has never been observed and is extremely unlikely (Marrone and Stout 1997).

To obtain broodfish for artificial spawning, Whitlock Bay Spawning Station was constructed and became operational in 1984. It is located near the midpoint of Lake Oahe, approximately $32 \mathrm{~km}$ west of Gettysburg, South Dakota, USA (Figure 1). Two large submersible pumps supply lake water to the raceways and fish ladder at the spawning station throughout the October Chinook salmon spawning season. As the water flows down the ladder, which consists of a series of metal weir plates that extends into the reservoir, (Figure 2), sexually mature salmon ascend the ladder and are subsequently spawned. At the upper terminal end of the ladder, the salmon swim through a funnel-shaped gate (Figure 3) into a catch raceway (13.7 $\mathrm{m}$ long, $2.4 \mathrm{~m}$ wide, $1.2 \mathrm{~m}$ deep) before being periodically sorted into one of three similarly-sized holding raceways (Figure 4) and eventually spawned. The station also has a 
crowding raceway and an enclosed building for spawning (Hanten 2011).

Approximately 1,000 salmon ascend the ladder during a given spawning season (Hanten et al. 2011). However, during certain years, relatively few females are present in the catch raceway, and the egg numbers produced are below the levels needed to meet restocking requests (Maahs et al. 2018). Thus, it is essential that feral broodstock returns to the station, and subsequent egg numbers, are maximized. It has always been assumed that all of the salmon ascending the fish ladder remained in the catch raceway. However, this assumption has never been verified. It was unknown how many, if any, spawning fish, escaped the catch raceway and swam back down the ladder. Thus, the objective of this study was to document the retention of feral fall Chinook salmon broodstock in the catch raceway at Whitlock Bay Spawning Station.

\section{Methods}

In October 2017, a mark-recapture study was conducted on salmon ascending the fish ladder at Whitlock Bay Spawning Station during normal spawning operations. Every fish that entered the catch raceway was tagged at the base of their dorsal fin with a uniquely numbered T-bar anchor tag (Floy Tag, Seattle, Washington, USA), and their sex and reproductive status documented. Males were returned to the catch raceway, where-as females were moved to other more secure raceways based on their reproductive status.

All of the salmon in the catch raceway were processed on Monday, Wednesday, and Friday of each week in October. Any new fish were tagged, recaptured fish (those already tagged) were recorded, females were moved, and any mortalities were recorded and removed from the catch raceway. The total number of tagged males and females was calculated, as well as the total number of tagged males that may have escaped. In addition, because catch raceway data was collected three times per week, the average residence time of male salmon in the catch raceway before escapement was estimated. Lastly, tag loss data from the tagged females in the secure raceways was collected and used to correct the estimated male escapement rate; males that lost a tag would be mistakenly designated as escapees.

\section{Results and Discussion}

A total of 383 male salmon ascended the fish ladder and were tagged. Of the tagged males, $159(41.5 \%)$ were initially designated as escaped from the catch raceway. Tag loss in the separately-held females was $3.9 \%$ (15 of 385 tags were lost). Thus, the estimated male salmon escapement rate from the catch raceway was $37.6 \%$. Male salmon remained in the catch raceway for one-to-three days before escaping. The escapement rate decreased over the month-long spawn, with nearly $60 \%$ of the males going back down the fish ladder in the first week of October, compared to fewer than $20 \%$ escaping by the final week.

These results clearly indicate that the long-held assumption of minimal escapement was erroneous. Female salmon were not included in the study due to their high value to the propagation program. However, these escapement rates could be particularly problematic if female salmon are behaving similarly to the males in this study. Given the high need for Lake Oahe salmon eggs and the relatively low observed egg survival rates (Barnes et al. 2000; 
Young et al. 2016), the potential loss of female salmon broodstock is of concern.

There are at least two potential solutions to solving the problem of salmon escapement from the catch raceway at Whitlock Bay Spawning Station. First, an additional barrier, or barriers, could be installed to make the fish ladder or funnel-shaped gate one-way only. Other locations capturing spawning salmon have successfully used this solution (FRED 1983; Brannon 1991; Schroeder 1996). This solution would likely require considerable ingenuity and re-engineering of the existing structure. Another potential solution is to remove salmon from the catch raceway more frequently than the three-times-per-week routine used in this study. Given that most escapements occurred within three days of fish arriving in the catch raceway, moving all of the fish daily from the catch raceway to other more secure locations at the spawning station would likely reduce escapement rates. Such an increase in fish handling comes with considerable costs and risks however. The labor and travel expenses required for every-day salmon moving would be high. In addition, the increased handling of broodstock would likely lead to increased egg mortality (Barnes et al. 1999; Cho et al. 2002; Huysman et al. 2018).

\section{Acknowledgments}

Special thanks to the Ft. Pierre fisheries staff for the labor and data collection that allowed for the publication of this data.

\section{References}

Barnes, M. E., Hanten, R. P., Cordes, R. J., Sayler, W. A., \& Carrerio, J. (2000). Reproductive performance of inland fall chinook salmon. North American Journal of Aquaculture, 62, 203-211. https://doi.org/10.1577/1548-8454(2000)062<0203:RPOIFC>2.3.CO;2

Barnes, M. E., Lott, J. P., Sayler. W. A., et. al. (1999). Practical observations on the use of eggs from electroshocked females during spawning of inland fall Chinook salmon. North American Journal of Aqualculture, 61, 162-166. https://doi.org/10.1577/1548-8454(1999)061<0162:POOTUO>2.0.CO;2

Brannon, E. L. (1991). Rainbow Trout Culture. Pages 22-55 in RR Stickney editor. Culture of Salmonid Fishes. CRC Press, Boca Raton, Florida, USA.

Cho, G. K., Heath, J. W., \& Heath, D. D. (2002). Electroshocking influences Chinook salmon egg survival and juvenile physiology and immunology. Transactions of the American $\begin{array}{lll}\text { Fisheries } \quad \text { Society, 224-233. } & \text { 131, }\end{array}$ https://doi.org/10.1577/1548-8659(2002)131<0224:EICSES>2.0.CO;2

FRED. (1983). Fish Culture Manual. Alaska Department of Fish and Game, Juneau, AK.

Hanten, R. (2011). 2010 Whitlock Bay Spawning Station Report. South Dakota Department of Game, Fish and Parks, Annual Report, 11(02).

Huysman, N., Voorhees, J. M., Meyer, H., Krebs, E., \& Barnes, M. E. (2018). Electrofishing of Landlocked Fall Chinook Salmon Broodstock Negatively Impacts Egg Survival. North American Journal of Aquaculture, October 2018, 80(4), 411-417. 
https://doi.org/10.1002/naaq.10058

Leitritz, E., \& Lewis, R. C. (1976). Trout and salmon culture (hatchery methods). California Department of Fish and Game, Fish Bulletin, pp. 164.

Lott, J., Marrone, G. M., \& Stout, D. A. (1997). Influence of size-and-date at stocking, imprinting attempts and growth on initial survival, homing ability, maturation patterns and angler harvest of Chinook Salmon in Lake Oahe, SD. South Dakota Department of Game, Fish and Parks, progress report.

Maahs, B. C., Meyer, H. A., \& Huysman, N. D., et. al. (2018). Mortality of Landlocked Fall Chinook Salmon Broodstock After Electrofishing or Ascending a Fish Ladder. JJ Aquacul Res 2018, 3(1), 019.

Marrone, G. M., \& Stout, D. A. (1997). 1997 Whitlock Bay Spawning Station Annual Report. South Dakota Department of Game, Fish and Parks, Annual Report, 97, 19.

McIntyre, J. D. (1991). Pacific Salmon Culture for Stocking. Pages 58-70 in RR Stickney editor, Culture of Salmonid Fishes. CRC Press, Boca Raton, Florida, USA.

Piper, R. G., McElwain, I. B., Orme, L. E., McCraren, J. P., Fowler, L. G., \& Leonard, J. R. (1982). Fish hatchery management. U.S. Fish and Wildlife Service, Washington, D.C.

Schroeder, R. K. (1996). A review of capture techniques for adult anadromous salmonids. Oregon Department of Fish and Game, Portland, OR.

Young, K. L., Barnes, M. E., \& Kientz, J. L. (2016). Reproductive characteristics of landlocked fall Chinook salmon from Lake Oahe, South Dakota. Prairie Naturalist, 48, 79-86. 


\section{Macrothink}

\section{Appendix}

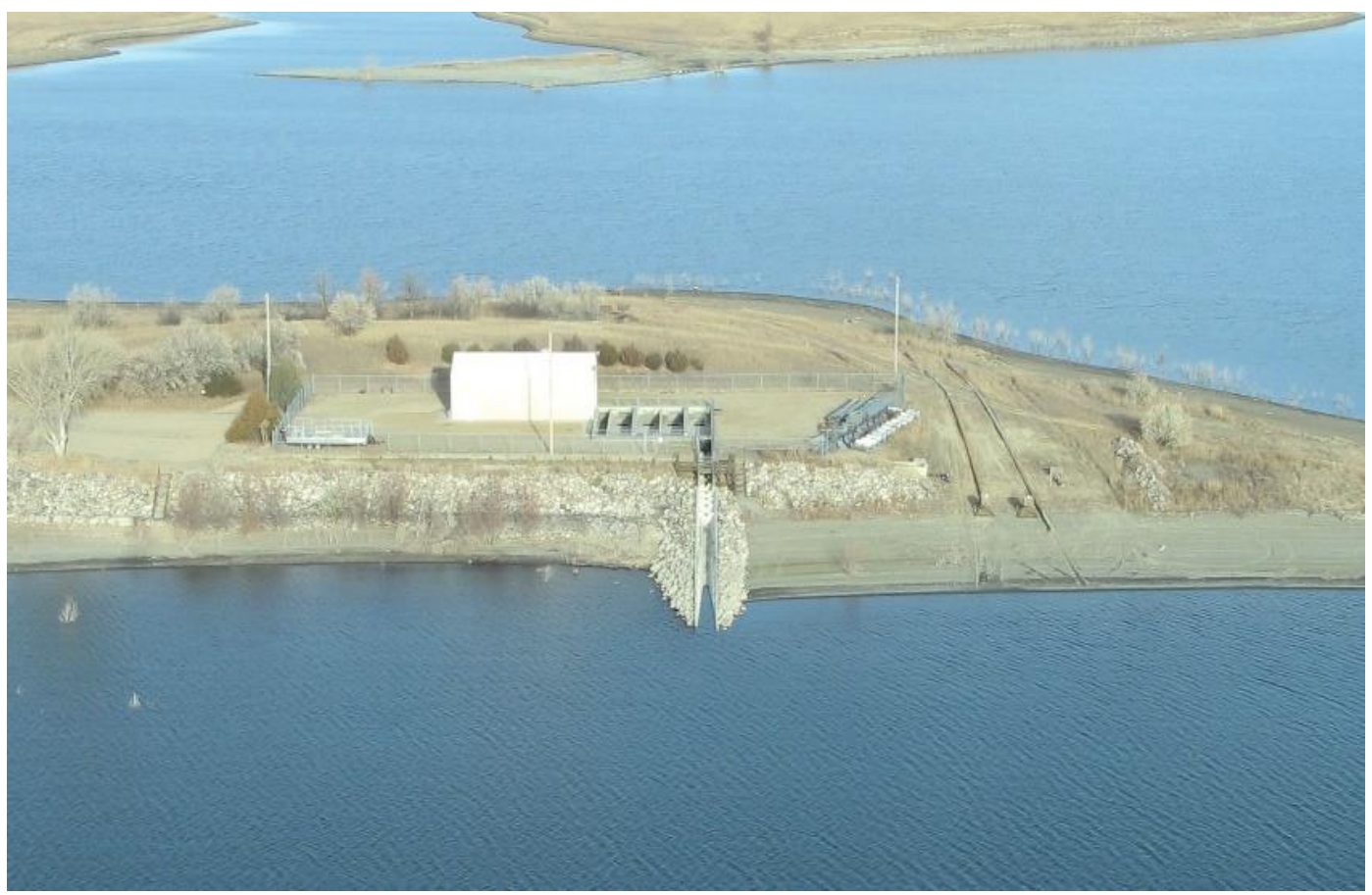

Figure 1. Aerial view of Whitlocks Spawning Station, Lake Oahe, South Dakota

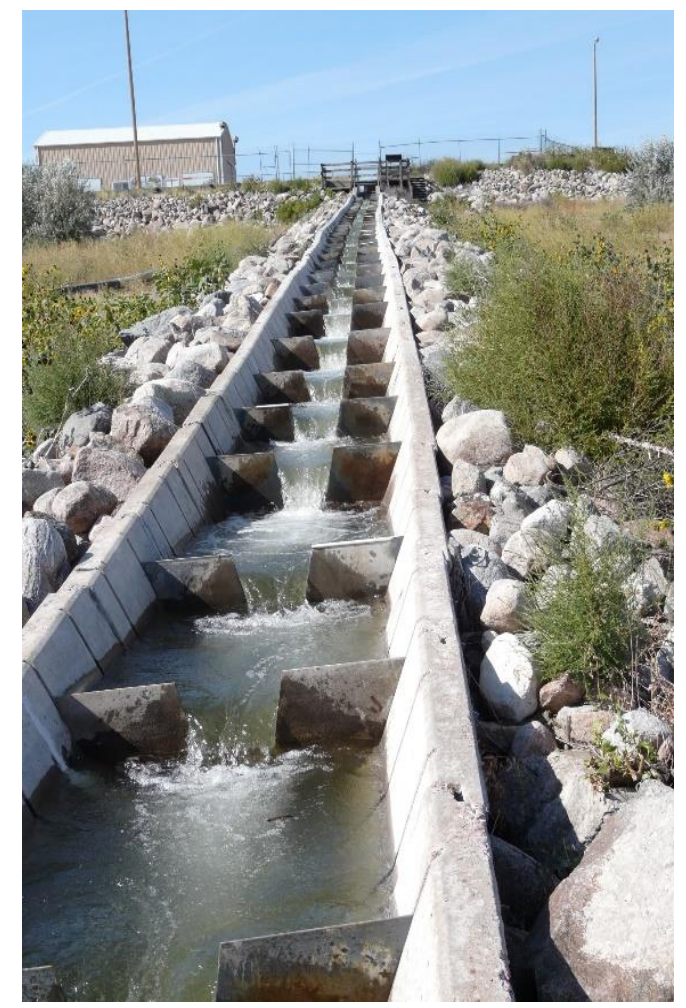

Figure 2. The fish ladder leading up into the catch raceway at Whitlocks Spawning Station, Lake Oahe, South Dakota 


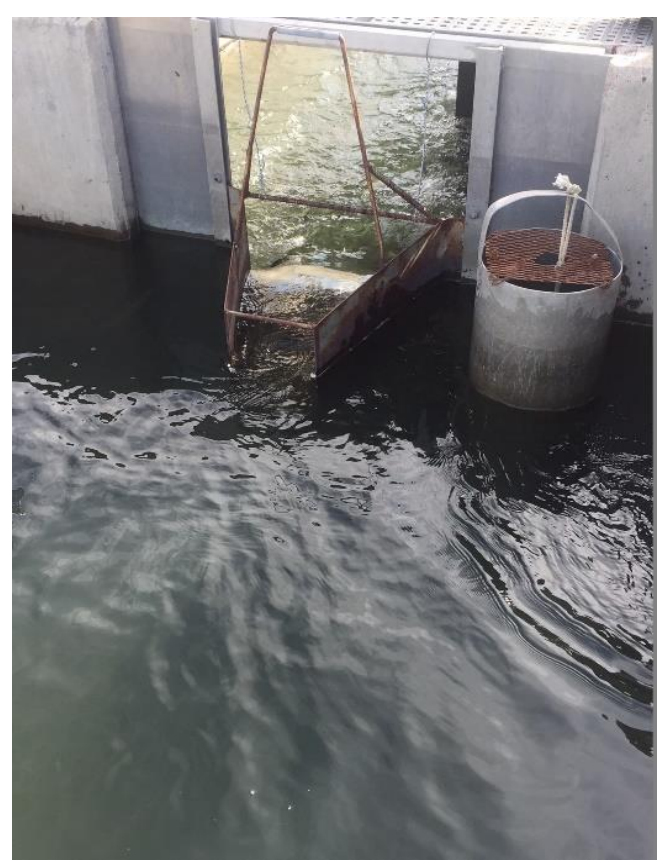

Figure 3. A close-up view of the funnel-shaped gate that leads into the catch raceway at Whitlocks Spawning Station, Lake Oahe, South Dakota

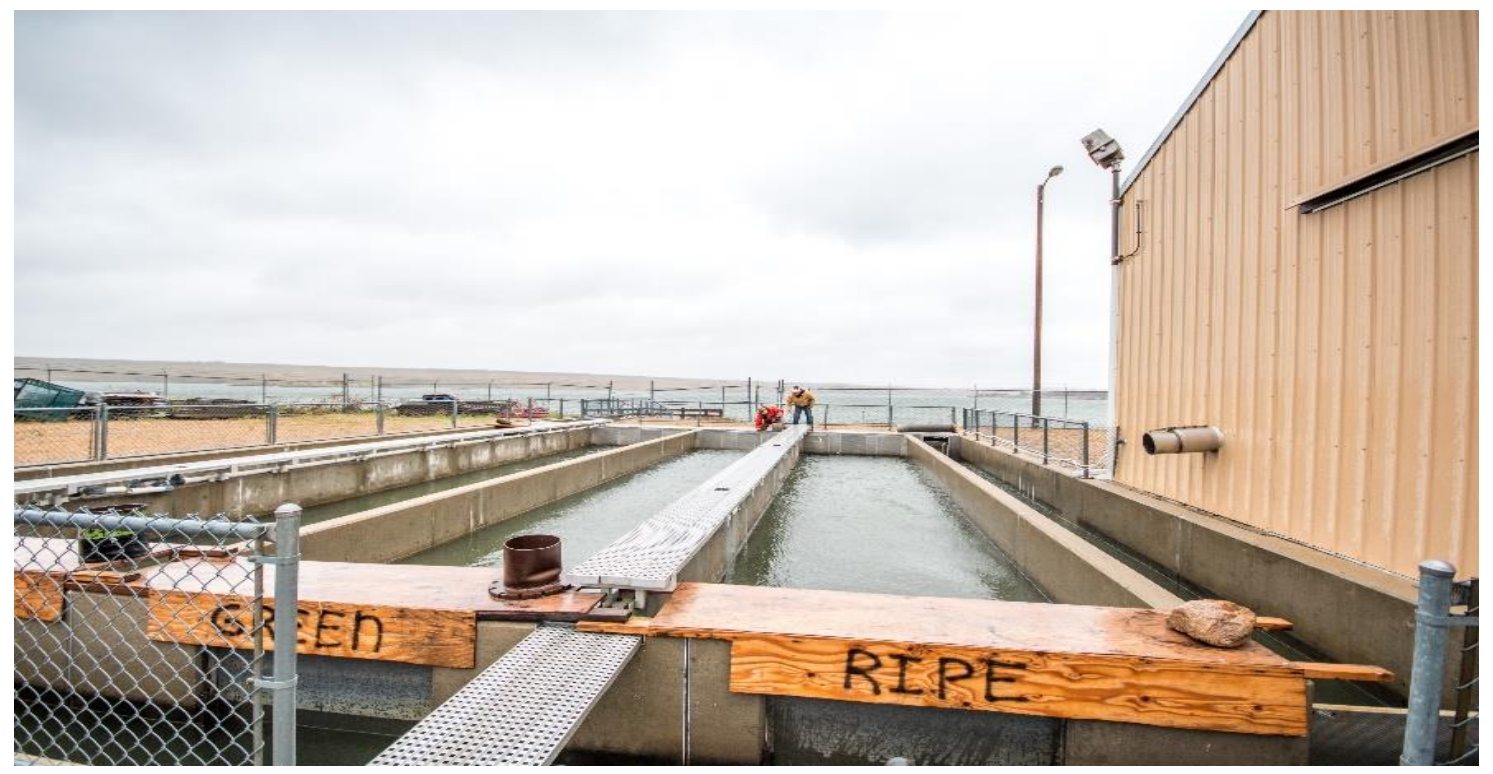

Figure 4. The secure raceways at Whitlocks Spawning Station, Lake Oahe, South Dakota where fish are held prior to being spawned after being removed from the catch raceway

\section{Copyrights}

Copyright for this article is retained by the author(s), with first publication rights granted to the journal.

This is an open-access article distributed under the terms and conditions of the Creative Commons Attribution license (http://creativecommons.org/licenses/by/4.0/) 